\title{
Synthesis, Characterization and Mössbauer Studies of Fe(II) and Fe(III) Complexes of 2-Acetylpyridine Thiosemicarbazone
}

\author{
Ruth H. U. Borges ${ }^{a}$, Anuar Abras ${ }^{b}$, and Heloisa Beraldo ${ }^{a} a$ \\ ${ }^{a}$ Departamento de Química, Icex, Universidade Federal de Minas Gerais, \\ 31270-901 Belo Horizonte - MG, Brazil \\ ${ }^{b}$ Departamento de Física, Icex, Universidade Federal de Minas Gerais,
} 31270-901 Belo Horizonte - MG, Brazil

Received: January 5, 1996; October 11, 1996

Foram obtidos e caracterizados três complexos de ferro da 2-acetilpiridina tiossemicarbazona (2APT): [Fe(HAPT)(APT) $\mathrm{Cl}_{2}$ (I), [ $\left.\mathrm{Fe}(\mathrm{HAPT})_{2}\right] \mathrm{Cl}_{2}(\mathrm{II})$, e $\left[\mathrm{Fe}(\mathrm{APT})_{2}\right]$ (III), nos quais HAPT representa o ligante protonado no nitrogênio N(2') da cadeia lateral e APT $^{-}$o ligante desprotonado em N(2'). A coordenação ao íon metálico ocorre através do sistema tridentado $\mathrm{N}_{\mathrm{py}} \cap \mathrm{N}\left(1^{\prime}\right) \cap(\mathrm{S})$, com a formação de complexos do tipo L:M 2:1. Os parâmetros Mössbauer $\delta$ (desvio isomérico) e $\Delta$ (desdobramento quadrupolar) são característicos de Fe(III) para o complexo I e de Fe(II) para os complexos II e III, todos de spin baixo e simetria octaédrica. $\mathrm{O}$ valor de $\delta$ diminui quando se passa do complexo $\left[\mathrm{Fe}(\mathrm{HAPT})_{2}\right] \mathrm{Cl}_{2}$ (II, $\delta=0,264 \pm 0,001 \mathrm{~mm} / \mathrm{s}$ ) ao complexo [Fe(APT) $)_{2}$ (III, $\delta=0,227 \pm 0,001$ $\mathrm{mm} / \mathrm{s}$ ), em razão da maior densidade eletrônica de eletrons s no metal no segundo complexo, resultante do efeito indutivo eletrodoador do grupo metila e da carga negativa no enxofre de tiolato que o tornam um melhor doador sigma do que o enxofre de tiona do primeiro complexo. O desdobramento quadrupolar $\Delta$ aumenta quando se passa do complexo protonado, II ( $\Delta=$ $0,537 \pm 0,002 \mathrm{~mm} / \mathrm{s})$ ao desprotonado, III $(\Delta=0,755 \pm 0,002 \mathrm{~mm} / \mathrm{s})$, provavelmente em razão da diferença na natureza dos dois ligantes, principalmente na ordem das ligações metal-enxofre.

Three iron complexes of 2-acetylpyridine thiosemicarbazone were obtained, namely $[\mathrm{Fe}(\mathrm{HAPT})(\mathrm{APT})] \mathrm{Cl}_{2}(\mathrm{I}),\left[\mathrm{Fe}(\mathrm{HAPT})_{2}\right] \mathrm{Cl}_{2}$ (II), and [Fe(APT) $)_{2}$ (III), in which HAPT stands for the ligand protonated at the $\mathrm{N}\left(2^{\prime}\right)$ level in the side chain and $\mathrm{APT}^{-}$for the ligand deprotonated at $\mathrm{N}\left(2^{\prime}\right)$. The coordination to the metal ion occurs through the tridentate ligating $\mathrm{N}_{\mathrm{py}} \cap \mathrm{N}\left(1^{\prime}\right) \cap(\mathrm{S})$, system with formation of 2:1 ligand-to-metal complexes having meridional stereochemistry. The Mössbauer parameters $\delta$ (isomer shift) and $\Delta$ (quadrupole splitting) are characteristic of Fe(III) for complex I and of Fe(II) for both complexes II and III, all low spin with octahedral geometry. The isomer shift value decreases in going from $\left[\mathrm{Fe}(\mathrm{HAPT})_{2}\right] \mathrm{Cl}_{2}$ (II, $\delta=0.264 \pm 0.001 \mathrm{~mm} / \mathrm{s}$ ) to [Fe(APT) $)_{2}$ (III, $\left.\delta=0.227 \pm 0.001 \mathrm{~mm} / \mathrm{s}\right)$, due to the higher s electron density of the latter. This results from the electron donor inductive effect of the acetyl methyl group and the negative charge of the thiolate sulfur, which is consequently a better sigma donor than the thione sulfur. The quadrupole splitting increases in going from II $(\Delta=0.537 \pm 0.002$ $\mathrm{mm} / \mathrm{s})$ to III $(\Delta=0.755 \pm 0.002 \mathrm{~mm} / \mathrm{s})$, probably due to ligand inequivalencies, a significant contribution being attributed to differences in the metal-ligand bond order.

Keywords: 2-acetylpyridine thiosemicarbazone, iron complexes

\section{Introduction}


thiosemicarbazones derived from 2-acetylpyridine have been shown to present a broad range of chemotherapeutic activities and have been evaluated for their antimalarial, antitumor, antibacterial and antifungal action ${ }^{2}$. The pharmacological activity of these compounds has often been related to their chelating ability with metal ions ${ }^{3}$.

In previous works we have undertaken studies on the metal complexes of 2-formylpyridine thiosemicarbazone $e^{4-6}$. The present report deals with the preparation, characterization and Mössbauer data of Fe(II) and Fe(III) complexes of 2-acetylpyridine thiosemicarbazone.

The ligand is a tridentate chelating $\mathrm{N}_{\text {py }} \cap \mathrm{N}\left(1^{\prime}\right) \cap \mathrm{S}$ system (see Fig. 1) that can coordinate metal ions either under the protonated (HAPT) or the deprotonated (APT) form at $\mathrm{N}\left(2^{\prime}\right)$. The former contains thione sulfur and the latter thiolate sulfur.

\section{Experimental}

\section{Synthesis}

The ligand HAPT was prepared according to standard procedures $^{7}$. The complex $[\mathrm{Fe}(\mathrm{HAPT})(\mathrm{APT})] \mathrm{Cl}_{2}$ (I) was prepared by adding 1.8 mmole $(3.3492 \mathrm{~g})$ of HAPT to a solution containing $0.9 \mathrm{mmol}(0.1461 \mathrm{~g})$ of anhydrous $\mathrm{FeCl}_{3}$ dissolved in $35 \mathrm{~mL}$ of hot ethanol, acidified at $\mathrm{pH} 4$ with $\mathrm{HCl}$. After $2 \mathrm{~h}$ at $70{ }^{\circ} \mathrm{C}$ the mixture was cooled and the brown precipitate formed was filtered and washed with ethanol, then ether and dried under vacuum over drierite (yield $45 \%$ ). The $\mathrm{C}, \mathrm{H}, \mathrm{N}, \mathrm{Fe}$ and $\mathrm{Cl}$ analysis were compatible with the formula $\mathrm{C}_{16} \mathrm{H}_{19} \mathrm{~N}_{8} \mathrm{~S}_{2} \mathrm{FeCl}_{2}, \mathrm{M}=514.03 \mathrm{~g} / \mathrm{mole}$ Found: $\mathrm{C} \%: 38.86 ; \mathrm{H} \%: 3.74 ; \mathrm{N} \%: 22.53 ; \mathrm{Fe} \%: 11.25 ; \mathrm{Cl} \%: 13.5$. Calcd.: C\%:37.35; H\%:3.70; N\%:21.79; Fe\%:10.89; $\mathrm{Cl} \%: 13.6$.

The complex $\left[\mathrm{Fe}(\mathrm{HAPT})_{2}\right] \mathrm{Cl}_{2}$ (II) was obtained by the additon of 1.8 mmole $(0.3492 \mathrm{~g})$ of HAPT to a hot solution of anhydrous $\mathrm{FeCl}_{2}(0.9$ mmole, $0.1141 \mathrm{~g})$ in $40 \mathrm{~mL}$ of ethanol. After $3 \mathrm{~h}$ at $70^{\circ} \mathrm{C}$ the reaction mixture was cooled and the violet brownish solid was filtered, washed with ethanol and ether and dried under vacuum over drierite (yield $57 \%$ ). The $\mathrm{C}, \mathrm{H}, \mathrm{N}$ analysis was compatible with the formula $\mathrm{C}_{16} \mathrm{H}_{20} \mathrm{~N}_{8} \mathrm{~S}_{2} \mathrm{FeCl}_{2}, \mathrm{M}=515.03 \mathrm{~g} / \mathrm{mole}$ Found: C\%:37.43; H\%:3.94; N\%:21.81. Calcd.: C\%:37.28; $\mathrm{H} \%: 3.88 ; \mathrm{N} \%: 21.75$.
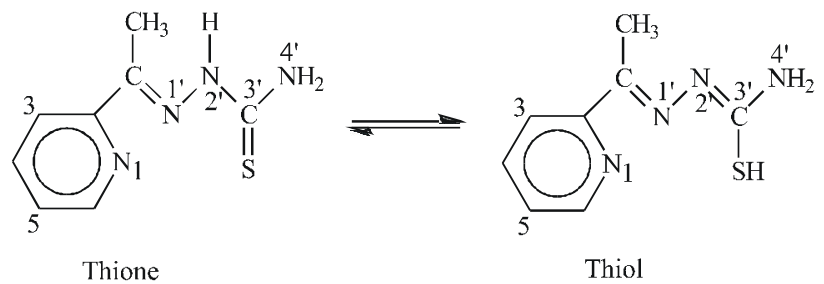

Figure 1. Structure of the ligand 2-acetylpyridine thiosemicarbazone under the thione and thiol tautomeric forms.
The complex [Fe(APT) $)_{2}$ (III) was obtained by addition of 1.8 mmole $(0.3492 \mathrm{~g})$ of HAPT to a hot solution of $\mathrm{FeCl}_{2}$ $(0.9 \mathrm{mmole}, 0.1141 \mathrm{~g})$ in $35 \mathrm{~mL}$ of ethanol. After the addition of the ligand, an equal volume of deionized water and a few drops of concentrated ammonia were added giving a green mixture. After $2 \mathrm{~h}$ at $70{ }^{\circ} \mathrm{C}$ the reaction mixture was cooled and the brownish green precipitate was filtered, washed with ethanol, followed by ether and dried under vacuum over drierite (yield 23\%). The $\mathrm{C}, \mathrm{H}, \mathrm{N}$ analysis was compatible with the formula $\mathrm{C}_{16} \mathrm{H}_{18} \mathrm{~N}_{8} \mathrm{~S}_{2} \mathrm{Fe}, \mathrm{M}=442.12$ g/mole Found: C\%:43.01; H\%:3.94; N\%:24.95. Calcd.: C\%:43.01; H\%:3.88; N\%:25.34.

All three complexes decompose upon heating: I at $262{ }^{\circ} \mathrm{C}$, II at $197^{\circ} \mathrm{C}$ and III at $303{ }^{\circ} \mathrm{C}$.

\section{Apparatus}

The atomic absorption spectra were obtained by means of a Varian Techtron AAG spectrometer and the neutronic activation analysis of chloride was obtained by means of a Cambera equipment provided with a $7229 \mathrm{Ge} / \mathrm{Li}$ detector. The molar conductance data were obtained by means of a YSI Conductivity Bridge, model 31, equipped with a condutimetric cell of cell constant equal to $0.088 \mathrm{~cm}^{-1}$, using $10^{-4} \mathrm{~mol} / \mathrm{L}$ solutions in methanol. $\mathrm{KCl}, \mathrm{KBr}, \mathrm{BaCl}_{2}$ and $\mathrm{Mg}\left(\mathrm{NO}_{3}\right)_{2} .6 \mathrm{H}_{2} \mathrm{O}$ were used as standards.

IR spectra were run in a Perkin Elmer 283 B instrument, using Nujol mulls.

Mössbauer spectra were obtained using a conventional constant acceleration spectrometer, moving a Co-Rh source at room temperature. All spectra were computer fitted assuming lorentzian line shapes.

\section{Results and Discussion}

For all compounds the $\mathrm{C}, \mathrm{H}, \mathrm{N}$ analysis indicated the presence of 1:2 metal to ligand complexes. In the case of complex I this analysis suggested the presence of one protonated and one deprotonated ligand attached to the metal ion (Fe(III)), whereas two protonated and two deprotonated ligands attached to Fe(II) are suggested in the case of complexes II and III respectively. In order to confirm the existence of one protonated and one deprotonated ligand in the same complex, the percentages of the metal and chloride were also determined for complex I, corroborating our assumption. Furthermore, the molar conductance of this complex $\left(148.5 \mathrm{~S} \mathrm{~cm}^{2} \mathrm{~mol}^{-1}\right)$ indicated that the complex is a 1:2 electrolyte, again confirming our supposition. In fact, some works report the synthesis of 2:1 ligand-to-metal complexes of other thiosemicarbazones having the two ligand molecules in different protonation states $^{8}$.

The infrared spectra of the complexes present characteristic features compared to that of the free ligand (Table 1). 
Table 1. Important I.R. bands and assignements for the ligand (HAPT) and its complexes: $[\mathrm{Fe}(\mathrm{HAPT})(\mathrm{APT})] \mathrm{Cl}_{2}(\mathrm{I}),\left[\mathrm{Fe}\left(\mathrm{HAPT}_{2}\right] \mathrm{Cl} \mathrm{l}_{2}(\mathrm{II}) \mathrm{e}\right.$ $\left[\mathrm{Fe}(\mathrm{APT})_{2}\right](\mathrm{III})$.

\begin{tabular}{|c|c|c|c|c|c|c|c|c|c|}
\hline compound & $v \mathrm{CC}$ py $+\delta \mathrm{NH}_{2}$ & $v \mathrm{CN}$ & $\begin{array}{l}\vee \mathrm{CN}+\delta \mathrm{NH}_{2} \\
\text { (thioamide II) }\end{array}$ & $v \mathrm{CS}+v \mathrm{NCN}$ & $\begin{array}{c}v_{\text {s py }} \\
\text { (ring breath) }\end{array}$ & $v \mathrm{CS}$ & $\delta$ in plane & $\begin{array}{c}\delta_{\text {out of }} \\
\text { plane }\end{array}$ & $v \mathrm{MS}$ \\
\hline \multirow[t]{3}{*}{ HAPT } & $1605 \mathrm{~s}$ & $1570 \mathrm{~s}$ & $1490 \mathrm{~s}$ & $1135 \mathrm{~s}$ & $985 \mathrm{~m}$ & $835 \mathrm{~s}$ & $630 \mathrm{~m}$ & $390 w$ & $320 w$ \\
\hline & & $1550 \mathrm{~m}$ & $1465 \mathrm{~s}$ & $1095 \mathrm{~s}$ & $970 \mathrm{~m}$ & $815 \mathrm{~s}$ & $600 \mathrm{~m}$ & $375 w$ & \\
\hline & & & $1425 \mathrm{~s}$ & $1075 \mathrm{~s}$ & $955 \mathrm{~m}$ & $760 \mathrm{~s}$ & $585 \mathrm{~m}$ & & \\
\hline \multirow[t]{3}{*}{ I } & $1620 \mathrm{~s}$ & & $1495 \mathrm{~s}$ & $1170 \mathrm{~s}$ & $950 w$ & $800 w$ & $650 \mathrm{~m}$ & $400 w$ & $350 w$ \\
\hline & $1600 \mathrm{~s}$ & & $1440 \mathrm{~s}$ & $1150 \mathrm{~s}$ & & $760 \mathrm{~m}$ & $625 \mathrm{~m}$ & & $325 w$ \\
\hline & & & & $1120 \mathrm{~s}$ & & & $590 \mathrm{~m}$ & & \\
\hline \multirow[t]{3}{*}{ II } & $1625 \mathrm{~s}$ & $1585 \mathrm{~s}$ & $1460 \mathrm{~s}$ & $1165 \mathrm{~s}$ & $1005 \mathrm{~m}$ & $795 w$ & $640 \mathrm{~m}$ & $400 w$ & $350 w$ \\
\hline & $1605 \mathrm{~s}$ & $1550 \mathrm{~s}$ & $1430 \mathrm{~s}$ & $1150 \mathrm{~s}$ & $985 \mathrm{~m}$ & & $595 \mathrm{~s}$ & & $315 w$ \\
\hline & & & & $1110 \mathrm{~m}$ & & & & & \\
\hline \multirow[t]{3}{*}{ III } & & $1590 \mathrm{~s}$ & $1425 \mathrm{~s}$ & $1160 \mathrm{~s}$ & $1000 \mathrm{~m}$ & $790 w$ & $635 \mathrm{w}$ & $410 \mathrm{~m}$ & $350 w$ \\
\hline & & $1565 \mathrm{~m}$ & & $1150 \mathrm{~s}$ & $975 \mathrm{~m}$ & $765 \mathrm{~m}$ & $600 \mathrm{~m}$ & $390 \mathrm{~m}$ & $305 \mathrm{~m}$ \\
\hline & & $1515 \mathrm{~m}$ & & $1115 \mathrm{~m}$ & & & & & \\
\hline
\end{tabular}

$\mathrm{s}=$ strong $\mathrm{m}=$ medium $\mathrm{w}=$ weak

The coordination of the pyridine nitrogen can be evidenced by the shifting of the ligand absorptions at 985 and $970 \mathrm{~cm}^{-1}$, attributed to the ring breath deformation ${ }^{9}$ to lower frequencies in the spectra of the complexes. Furthermore, the ligand absorptions at 630 and $375 \mathrm{~cm}^{-1}$, ascribed to the in plane and out of plane ring deformations respectively ${ }^{10}$ shift to higher frequencies in the spectra of the complexes. In addition, the band at $1605 \mathrm{~cm}^{-1}$, attributed to the $v_{\mathrm{CC}}$ ring stretching vibration also is shifted to higher frequencies upon complexation ${ }^{11}$. However, the latter normally occurs in the same region as the $\mathrm{NH}_{2}$ deformation $\left(1610-1615 \mathrm{~cm}^{-1}\right)$ or as the $v_{\mathrm{CN}}$ stretching around $1580 \mathrm{~cm}^{-1}$ not allowing an unumbiguous interpretation of the spectra in this region ${ }^{12}$.

The coordination of the azomethine nitrogen $\mathrm{N}\left(1^{\prime}\right)$ is indicated by the shifting of the ligand absorptions at 1550 , 1490 and $1425 \mathrm{~cm}^{-1}$, ascribed to the stretching $v_{\mathrm{CN}}$ or to the $v_{\mathrm{CN}}+\delta_{\mathrm{NH} 2}$ mode (thioamide II), to higher frequencies in the spectra of the complexes ${ }^{13-15}$.

A set of three intense bands at 1135, 1095 and 1075 $\mathrm{cm}^{-1}$ is believed to have a $v_{\mathrm{CS}}$ contribution ${ }^{16}$. This set of bands is shifted to lower frequencies upon coordination, appearing with lower intensity in the spectra of the complexes, indicating the attachment of the sulfur to the metal in all cases. Moreover, the spectrum of the free ligand exhibits two strong bands at 835 and $815 \mathrm{~cm}^{-1}$, which are usually assigned mainly to the $v_{C S}$ vibration. These absorptions are shifted 35 to $45 \mathrm{~cm}^{-1}$ to lower frequencies with diminution of intensity in the spectra of the complexes, suggesting the coordination of the sulfur ${ }^{17-18}$. Other authors observed a similar shifting of the $v_{\mathrm{CS}}$ vibration upon complexation ${ }^{10,15,19}$. In fact, when the protonated HAPT is coordinated, the thione sulfur is able to accept electron density from the metal through back $\pi$ bonding, leading to an increase of the M-S bond order and the concomitant decrease in the $\mathrm{C}-\mathrm{S}$ bond order. On the other hand, when coordinated as the deprotonated ( $\mathrm{APT}^{-}$) form, the tiolate sulfur is not as good a $\pi$ acceptor $^{20}$. Thus, the CS bond presents a double bond character due to the high delocalization of the negative charge in the ligand's chain, leading again to a strengthening of the M-S bond with the corresponding decrease in the C-S bond order. Therefore, the infrared data do not allow a clear distinction between thione and thiolate sulfur. In conclusion, the IR spectra clearly indicate the coordination of the ligand as a tridentate chelating $\mathrm{N}_{\mathrm{py}} \cap \mathrm{N}\left(1^{\prime}\right) \cap \mathrm{S}$ system.

The Fe- $\mathrm{S}$ vibration is assigned to the absorptions in the $340-380 \mathrm{~cm}^{-1}$ region, based on reports of other authors ${ }^{10,21}$, although the literature also contains reports atributing these bands to the Fe-N vibration and that at $400 \mathrm{~cm}^{-1}$ to the $\mathrm{Fe}-\mathrm{S}$ vibration $^{22}$.

In a recent work ${ }^{23}$ we reported the visible spectral assignments for complexes I, II and III. In aqueous solution the protonated $\mathrm{Fe}$ (II) complex (II), shows a band at $575 \mathrm{~nm}$ with a shoulder at $518 \mathrm{~nm}$. Upon deprotonation resulting in the formation of complex III, the maximum at $575 \mathrm{~nm}$ shifts to $600 \mathrm{~nm}$ and the shoulder to $545 \mathrm{~nm}$. From resonance Raman data obtained previously for the analogous complexes of 2-formypyridine thiosemicarbazone (HFPT), we attributed the spectral maxima to ligand-to-metal charge transfer transitions (LMCT) from a $\mathrm{p} \pi$ orbital of the thione/thiolate sulfur to a $\sigma^{*}$ orbital of the 
low spin $\mathrm{Fe}(\mathrm{II})$. The shoulder was indicated to be due to a vibronic structure corresponding to a transition to an excited vibrational level ${ }^{11}$. The same assignment is suggested for the bands in the visible spectra of complexes II and III (both low spin, as shown by Mossbauer spectroscopy, vide infra). In fact, on deprotonation the energy of this transition decreases due to the the lower energy of the charge transfer from the thiolate sulfur orbital compared to the thione sulfur orbital. This energy difference results because the the thiolate sulfur is more polarizable. That is, the greater $p$ character of the $\mathrm{sp}^{3}$ hybridization of the thiolate sulfur compared to the $\mathrm{sp}^{2}$ hybridization of the thione sulfur makes the thiolate a better $\mathrm{p} \pi$ donor. As we demonstrated before, resonance Raman data as well as the low energy of the absorption maxima in the visible precluded the assignment of the peak to a $\sigma(\mathrm{S})-\sigma^{*}(\mathrm{M})$ charge transfer transition ${ }^{11,24}$. The latter is probably superimposed to the intraligand transitions in the ultraviolet range (Fig. 2).

The visible spectrum of the Fe(III) complex (I) shows a shoulder at $440 \mathrm{~nm}$, which we assigned to a $\mathrm{p} \pi(\mathrm{S})-\sigma^{*}(\mathrm{M})$ LMCT, similar to the previously studied Fe(III) complex of HFPT $^{11}$. Because of the larger $10 \mathrm{Dq}$ associated with low spin Fe(III) (Mossbauer data, vide infra) compared to that of low spin $\mathrm{Fe}$ (II) resulting from the higher charge $\mathrm{e}^{25}$, the charge transfer transition to $\sigma^{*}(\mathrm{Fe}(\mathrm{III}))$ is higher in energy than to $\sigma^{*}(\mathrm{Fe}(\mathrm{II}))$.

The Mössbauer spectra of complexes I, II and III are shown in Fig. 3. Table 2 gives the Mössbauer experimental

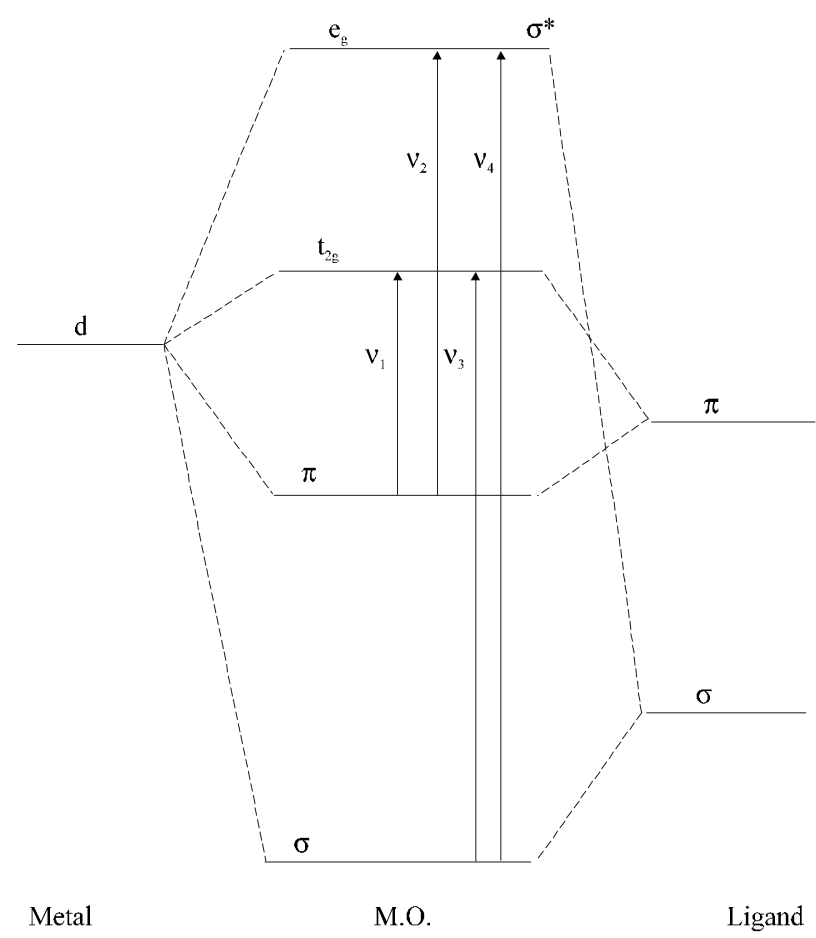

Figure 2. A simplified molecular orbital diagram illustrating the potential ligand-to-metal charge transfer transitions. Transitions to $t_{2 g}$ are absent in the low spin Fe(II) complexes. data, as well as those of the Fe(III) complex of the related ligand diacetyl monoxime thiosemicarbazone (IV), studied by other authors ${ }^{13}$. Complex IV is represented by [Fe(DMT-H)(DMT-2H)] in which DMT-H and DMT-2H stand for the ligand diacetyl monoxime thiosemicarbazone containing a thione and a thiolate sulfur respectively (i.e., the other hydrogen is lost from the monoxime moiety).

The Mössbauer spectrum of complex I is an asymmetric doublet, the second line being only $65 \%$ as intense as the first one. The narrow band width of the doublet $(\Gamma=0.242$ $\mathrm{mm} / \mathrm{s}$ ) indicates that the most intense line at around 1.25 $\mathrm{mmm} / \mathrm{s}$ is not due to any impurity but probably to a preferential orientation of the crystals or to vibrational anisotropy of the Mossbauer isotope in the crystal lattice.

The Mossbauer spectrum of complex I was also recorded at room temperature, in which the plane of the sample was rotated by $50^{\circ}$ with respect to the $\gamma$-ray direction. The parameters obtained were $\delta=0.063 \pm 0.002 \mathrm{~mm} / \mathrm{s}, \Delta=$ $2.426 \pm 0.004 \mathrm{~mm} / \mathrm{s}$ and $\Gamma=0.248 \pm 0.003 \mathrm{~mm} / \mathrm{s}$, that are essentially the same as the ones reported in Table 2, except that now the second line is $98 \%$ as intense as the first. This result indicates that the asymmetry of the doublet of complex I depends on the orientation of the crystals in the sample holder, which is characteristic of the texture effect ${ }^{26}$. Therefore, the asymmetric Mossbauer doublet shown by

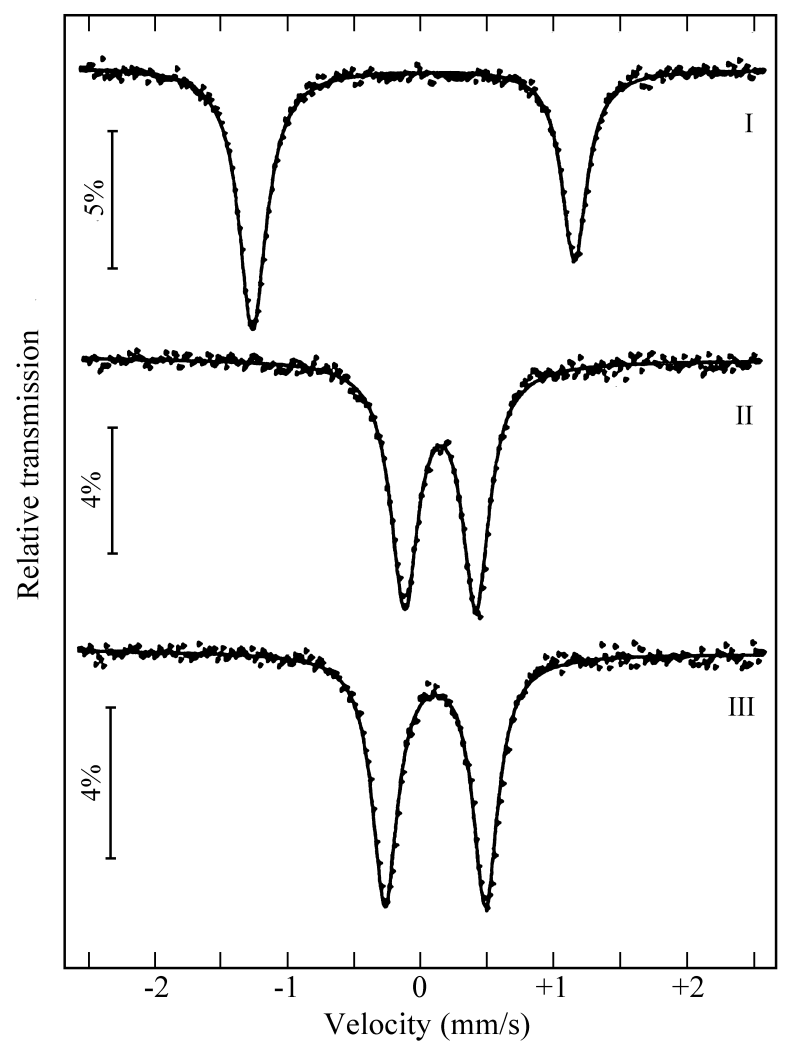

Figure 3. Mössbauer spectra at $298 \mathrm{~K}$ of the complexes: [Fe(HAPT) $(\mathrm{APT})] \mathrm{Cl}_{2}$ (I), $\left[\mathrm{Fe}(\mathrm{HAPT})_{2}\right] \mathrm{Cl}_{2}$ (II) and [Fe(APT) $)_{2}$ (III). 
Table 2. Mössbauer parameters at $298 \mathrm{~K}$ ( $\delta$ relative to metallic iron).

\begin{tabular}{lcccc}
\hline Complex & $\delta(\mathrm{mm} / \mathrm{s})$ & $\Delta(\mathrm{mm} / \mathrm{s})$ & $\Gamma^{\#}(\mathrm{~mm} / \mathrm{s})$ & Ref. \\
\hline (I) $\left[\mathrm{Fe}(\mathrm{HAPT})(\mathrm{APT}) \mathrm{Cl}_{2}\right.$ & $0.065 \pm 0.001$ & $2.430 \pm 0.002$ & $0.242 \pm 0.002$ & $*$ \\
(II) $\left[\mathrm{Fe}(\mathrm{HAPT})_{2}\right] \mathrm{Cl}_{2}$ & $0.264 \pm 0.001$ & $0.537 \pm 0.002$ & $0.251 \pm 0.002$ & $*$ \\
(III) $\left[\mathrm{Fe}(\mathrm{APT})_{2}\right]$ & $0.227 \pm 0.001$ & $0.755 \pm 0.002$ & $0.232 \pm 0.002$ & $*$ \\
(IV) $[\mathrm{Fe}(\mathrm{DMT}-\mathrm{H})(\mathrm{DMT}-2 \mathrm{H})]$ & 0.07 & 2.2 & & 13 \\
\hline
\end{tabular}

${ }^{\#} \Gamma=$ band width $*$ this work

complex I is mainly due to preferential orientation of the crystals. The spectra of complexes II and III show symmetric doublets.

The isomer shift $(\delta)$ relative to metallic iron and the quadrupole splitting $(\Delta)$ parameters are characteristic of low spin $\mathrm{Fe}$ (III) for complexes I and of low spin $\mathrm{Fe}(\mathrm{II})$ for complexes II and III, and all compounds having approximately octahedral geometry. The isomer shift of $\left[\mathrm{Fe}(\mathrm{HAPT})_{2}\right] \mathrm{Cl}_{2}$ (II, $\left.\Delta=0.264 \pm 0.001 \mathrm{~mm} / \mathrm{s}\right)$ is higher than that of [Fe(APT) $)_{2}$ (III, $\delta=0.227 \pm 0.001 \mathrm{~mm} / \mathrm{s}$, Table 2). The lower $\delta$ value of the deprotonated form can be interpreted in terms of an increase in the selectron density at the metal resulting from the negatively charged thiolate sulfur $^{20}$. This greater electron density is also facilitated by the acetyl methyl group's donation via the conjugated system of the anionic thiosemicarbazone ligand. In fact, thiolate sulfur is better a $\sigma$ as well as a p $\pi$ donor to $\mathrm{Fe}(\mathrm{II})$ than thione sulfur. Both sulfurs possess vacant $\mathrm{d} \pi$ orbitals that can be used for $\mathrm{d} \pi-\mathrm{d} \pi$ metal-sulfur bonding. Although thione sulfur is less polarizable than thiolate sulfur, it appears to be a better $\mathrm{d} \pi$ electron acceptor than the negatively charged thiolate sulfur ${ }^{26}$. Therefore, the electronic density at the iron(II) center is lower for the protonated (thione) complex (II) than for the deprotonated (thiolate) complex (III), in accordance with the higher $\delta$ value for complex II. Moreover, as we stated before, the energy of the LMCT transition in the electronic spectrum is lower for the deprotonated complex (III), again in accordance with the higher donor ability of the thiolate sulfur.

For the Fe(II) complexes the quadrupole splitting increases appreciably in going from the protonated (II, $\Delta=$ $0,537 \pm 0.002 \mathrm{~mm} / \mathrm{s}$ ) to the deprotonated (III, $\Delta=0.755 \pm$ $0.002 \mathrm{~mm} / \mathrm{s}$ ) form. In order to explain this variation ligand inequivalencies must be taken into consideration, a significant contribution being attributed to the difference in the $\mathrm{Fe}-\mathrm{S}$ bond order. Thiolate sulfur is able to form one $\sigma$ and two $\pi$ bonds with the metal whereas thione sulfur can only form one $\pi$ and one $\sigma$ bonds. Another significant contribution may be ascribed to the negative charge at the thiolate sulfur, the thione sulfur being neutral ${ }^{20}$. Again these results are in perfect agreement with the lower energy of the thiolate-to-metal charge transfer transition, due to its higher donor ability.

At this stage it is worth noting the similarities of the Mössbauer parameters of the $\mathrm{Fe}($ III) complexes $[\mathrm{Fe}(\mathrm{HAPT})(\mathrm{APT})] \mathrm{Cl}(\mathrm{I}, \delta=0.065 \pm 0.001 \mathrm{~mm} / \mathrm{s}, \Delta=2.430$ $\pm 0.002 \mathrm{~mm} / \mathrm{s})$ and its analog [Fe(DMT-H)(DMT-2H)] (IV, $\delta=0.07 \mathrm{~mm} / \mathrm{s}, \Delta=2.2 \mathrm{~mm} / \mathrm{s})$. Both the isomer shift and the quadupole splitting of I and IV are comparable, indicating that our formulation of compound I as containing one protonated and one deprotonated ligands is correct.

\section{Acknowledgments}

This work was supported by Conselho Nacional de Desenvolvimento Científico e Tecnológico (CNPq).

We are indebted to professor Douglas X. West for helpful discussion and suggestions.

\section{References}

1. Garg; B.S.; Prathapachandra Kurup, M.R.; Jain, S.J.; Bhoon, Y.K. Transition Met. Chem. 1988, 13, 309.

2. Scovill, J.P.; Klayman, D.L.; Franchino, C.F. J. Med. Chem. 1982, 25, 1261.

3. Scovill, J.P.; Klayman, D.L.; Lambros, G.E.; Childs, J.D.N. J. Med. Chem. 1984, 27, 87.

4. Beraldo, H.; Tosi, L. Inorg. Chim. Acta 1983, 75, 249.

5. Beraldo, H.; Tosi, L. Inorg. Chim. Acta 1986, 125, 173.

6. Abras, A.; Beraldo, H.; Fantini, E.; Borges, R.H.; da Rocha, M.A.; Tosi, L. Inorg. Chim. Acta 1990, 172,113 .

7. Anderson, F.L.; Duca, F.J.; Scudi, J.V. J. Am. Chem. Soc. 1951, 73, 4967.

8. West, D.X.; Makeever, J.P.; Scovill, J.P.; Klayman, D.L. Polyhedron 1984, 3, 947.

9. Corrsin, L.; Fax, B.J.; Lord, R.C. J. Chem. Phys. 1953, 21, 1170.

10. West, D.X.; Huffman, D.L. Transition Met. Chem. 1989, 14, 195.

11. Beraldo, H.; Tosi, L. Inorg. Chim. Acta 1983, 75, 249.

12. West, D.X.; White, A.C.; Sharif, F.D.; Gebremedhin, H.; Liberta, A.E. Transition Met. Chem. 1993, 18, 238. 
13.Raina, R.; Srivastava, T.S. Indian J.Chem1983, 22A, 701.

14. Scovill, J.A.; Klayman, D.L.; Franchino, C.F. J. Med. Chem. 1982, 25, 1261.

15. Bell, C.F.; Lott, K.A.K.; Hearn, N. Polyhedron 1987 , 6,39 .

16. Parwana, H.K.; Singh, G. Indian J. Chem. 1987, 26, 581.

17. Campbell, M.J.M. Coord. Chem. Rev. 1975, 15, 279.

18. Campbell, M.J.M.; Grzeskariak, R. J. Chem. Soc. A 1967, 396.

19. West, D.X.; Scovill, J.P.; Silverton, J.V.; Bavoso, A. Transition Met. Chem. 1986, 11, 123.

20. Abras, A.; da Rocha, M.A.; Beraldo, H.; Tosi, L. J. R. Neth. Chem. Soc. 1987, 106, 390.
21.West, D.X.; Ahrweiler, P.M.; Ertem, G.; Scovill, J.P.; Klayman, D.L.; Flippen-Anderson, J.L.; Gilardi, R.; George, C.; Pannell, L.K. Transition Met. Chem.1985, 10, 264.

22. Mohan, M.; Kumar, A.; Madhuranath, P.H.; Jha. N.K. J. Inorg. Biochem. 1988, 33, 121.

23. Borges, R.H.U.; Paniago, E.; Beraldo, H. in J. Inorg. Biochem (in press).

24. Lever, A.B.P. In Inorganic Electronic Spectroscopy; Elsevier Science Publishers Company Inc.: New York, 1984; p.204.

25. Huheey, J.E.; Keiter, E.A.; Keiter, R.L. In Inorganic Chemistry. Principles of Structure and Reactivity, $4^{\text {th }}$ Ed., Harper Collins College Publishers, New York, 1993. p 406.

26. Pfannes, H.D.; Gonser, U. Appl. Phys. 1973, 1, 93.

27. Akbar Ali, M.; Livingstone, S.E. Coord. Chem. Rev. 1974, 13, 101. 